International Journal of Linguistics, Literature and Translation

ISSN: 2617-0299 (Online); ISSN: 2708-0099 (Print)

DOI: $10.32996 / \mathrm{jjllt}$

Journal Homepage: www.al-kindipublisher.com/index.php/ijltt

\title{
"Do you speak Corona?": Hashtags and Neologisms since the COVID-19 Pandemic Outbreak
}

\author{
Qasim Obayes Al-Azzawi ${ }^{1}$ \& (D) and Haneen Ali Haleem ${ }^{2}$ 8 (D) $ه$ \\ ${ }^{1}$ Professor (PhD), Department of English, College of Education for Human Sciences, University of Babylon, Hilla, Iraq \\ 2MA Candidate, Department of English, College of Education for Human Sciences, University of Babylon, Hilla, Iraq. \\ $\triangle$ Corresponding Author: Haneen Ali Haleem, E-mail: Haneen.salih@student.uobabylon.edu.iq
}

\begin{tabular}{|c|c|}
\hline ARTICLE INFORMATION & ABSTRACT \\
\hline $\begin{array}{l}\text { Received: March 14, } 2021 \\
\text { Accepted: April 18, } 2021 \\
\text { Volume: } 4 \\
\text { Issue: } 4 \\
\text { DOI: } 10.32996 / \text { ijllt.2021.4.4.12 }\end{array}$ & $\begin{array}{l}\text { With the current outbreak of COVID-19, our everyday lifestyle has changes } \\
\text { thoroughly. Not only the economy, industry and health services witnessed major } \\
\text { alterations, but even our ways of communication. This can be found in the linguistic } \\
\text { changes that have occurred to the English language since the pandemic started. The } \\
\text { main phenomenon witnessed is the appearance of new terms and expressions, which } \\
\text { are analysed and discussed in this paper. The main aim is to identify these }\end{array}$ \\
\hline KEYWORDS & $\begin{array}{l}\text { developments, followed by their classification using Krishnamurthy's framework of } \\
\text { Neologism (2010). The dataset consists of over } 5 \text { million tweets collected between }\end{array}$ \\
\hline $\begin{array}{l}\text { COVID-19, Hashtags, Word } \\
\text { formation, Neologism, Online } \\
\text { Discourse, Social Media, Twitter }\end{array}$ & $\begin{array}{l}\text { January and June, 2020, which is analysed both qualitatively and quantitatively. The } \\
\text { result analysis indicated that these changes functioned as a tool of coping with the } \\
\text { major changes that happened to people's lifestyles globally. It was observed that } \\
\text { social media in general, and the hashtags in particular, had a significant impact on its } \\
\text { spreading. }\end{array}$ \\
\hline
\end{tabular}

1. Introduction

Social networking has always been a distinct feature of human communication and an integral part of their daily life. The recent technological developments, such as the emergence of mobile smartphones and the spread of internet had a fundamental role in digitalizing this act of social networking. The internet has developed from a restricted source of sharing information to widespread communication, partially through social media platforms. Such changes in communication are accompanied with developments in the language used in these platforms, the co-called cyber-language, as a number of linguistic phenomena have been observed. The most remarkable one is the hashtag, which started as a tool of organizing microblogging posts on Twitter, and became a multi-functional linguistic entity in online discourse over time.

The outbreak of the COVID-19 pandemic at the beginning of 2020 has affected societies globally, particularly by means of social distancing measures, travel bans and limitations, self-quarantines and business closures. Given the fact that people are forced to avoid public places, the majority of conversations about COVID-19 and its impact on daily life have shifted to social media platforms like Twitter. Since its advent, the new coronavirus has brought a totally new approach to people's life over the world and language has not been spared. Because it is dynamic, language changes to accommodate new happenings in society through word formation processes known as neologisms, languages can be adapted to reflect changes taking place in the life and culture of users, and the majority of such changes happen in their vocabulary because as compared to vocabularies that can change very quickly both in its lexicon and in word meanings, grammatical and phonological structures of language are relatively stable and take time to change.

This paper presents an analysis of language in social crisis, as it examines neologisms in the wake of COVID-19 by shedding light on how some of the words and phrases being used in the so-called corona vocabulary came into existence. We explore and explain some of the new ways of referring to things manifested in language during the pandemic. Through a descriptive

\section{K C AL-KINDI CENTER \\ $\mathbf{R}$ D FOR RESEARCH AND DEVELOPMENT}

Your gateway to world-class research

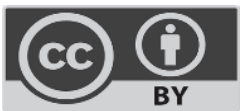

Published by Al-Kindi Center for Research and Development, London, United Kingdom. Copyright (c) the author(s). This open access article is distributed under a Creative Commons Attribution (CC-BY) 4.0 license 
qualitative method, an analysis of neologisms is presented, including new words added to the English vocabulary, based on Krishnamurthy's theoretical model of Neologisms (2010). The dataset consists of about 5 million tweets in English with 2.8 million COVID-19 related hashtags that have been collected between January and June, 2020 through Twitter's search API.

\section{Literature Review}

The impact of the COVID-19 pandemic has been of interest to researchers in various scientific disciplines. To cope with the virus outbreak, daily life habits and behaviour need to be adjusted, particularly for aligning human behaviour with the recommended norms as by health specialists (Goldberg et al., 2020; Van Bavel et al., 2020). Due to the fact that events, conferences, schools and colleges were forced to be cancelled and shut down, the majority of social interaction shifted to online forms of media which became a source of both information and social company (Asif et al., 2019).

Given the dynamicity of language, it is affected by a number of variables and factors that result into creating new words, phrases and expressions, along with a shift in meaning of technical terms originally related to fields of sociology, psychology, or medicine. As it represents a mixture of ideas and thoughts, language tends to generate and coin new expressions and words for accomplishing the needs of conversation. This illustrates how the public is responsible for the development of so-called "national conversation", using their own set of creative expressions for filling the gaps in the original discourse. Journalists and Twitter users are especially influential when it comes to word coinage, whereby a high level of linguistic ingenuity is involved. The current study presents an overview of the most commonly used vocabulary related to COVID-19 which implies the new lifestyle during the pandemic, reflecting the experiences of life under lockdown.

The appearance and creation of new words is a linguistic phenomenon called neologism. Crystal (2001) defines it as the foundation of new lexical items that are accepted into the language of a certain speech community during a particular period of time. Such expressions often develop during the establishment of new fields in arts, sciences or technology, such as with computer sciences (software, cloud computing, data mining). As for the present study, the neologisms that have been obtained resulted from a global crisis that affected our daily lifestyle thoroughly within a few months only. It represents a crucial means for examining the variation of change in languages over time (Khan, 2013).

There are a number of related works that shed light on the linguistic developments during the COVID-19 pandemic, particularly in terms of neologisms. To start with, Mweri (2020) presented a descriptive, qualitative analysis of new vocabulary related to the new corona virus, based on words and phrases that recur in social media and daily newspapers. Her analytic framework mainly depended on the theoretical (Rets, 2014) and functional (Halliday, 2013) approaches to neologisms. She concluded that languages change to accommodate new events that take place in society, such as the COVID19, and justified that the changes occur on the lexical level of language rather than the grammatical or phonological one.

Roig-Marin (2020) presented a short survey of the COVID19 vocabulary, arguing that the coinage of cyber-blends reflects the blended digital/physical relations in the present-day lifestyle. Online discourse has witnessed an increased use of vocabulary that was not used as much before the COVID19 or only known to few (jargon). She classified the different means of creating neologisms and briefly described each, including blending, compounding, or loanwords.

Alyeksyeyeva, Chaiuk, and Galitska (2020) examined the new cultural practices since the COVID pandemic through neologisms. They stated that modern-English speaking societies underwent different social and political changes causing the COVID19 to be a turning point in history. They pointed out a number of aspects that were highlighted throughout this process, namely a new categorization method for social groups based on their attitude towards the virus and the development of new practices or modification of old ones as part of daily lifestyle. They concluded that the neologisms represent an insight into novel cultural practices and a perception of the pandemic as a reference point in history.

Al-Salman and Haider (2021) described the trending neologisms and word-formation processes in English since COVID19. Through conducting a corpus analysis, it was revealed that there were many different forms of word-formation involved in creating the new corona vocabulary, including blending, clipping, acronyms, and compounding. They made a distinction between single-word and dual-word formation processes. The conclusion was drawn that the English language is indeed creative and vital in responding to emergency situations and times of crisis.

\section{Methodology}

With Twitter as the main data source, the dataset consists of over 5 million tweets collected between January and June, 2020 through Twitter's search API. These tweets are manually filtered based on a number of criteria. First and foremost, the tweet should mention COVID19 or be related to it in some form or other and include a relevant hashtag. Since the study is limited to English only, any tweets that are not in English are excluded. The remaining tweets included about 2.8 million tweets that were of 
relevance. Out of the remaining tweets, the covid-related hashtags are selected and classified into common words and neologisms. Then, the neologisms are classified into three types in light of Krishnamurthy's theoretical model (2010) .

He states that there are three components involved in neologisms, namely word formation, borrowing, and lexical deviation. Word formation is the etymological process used in language for creating new words, mostly through the coinage of words that have obtained a novel meaning. Lexical deviation involves the denotational approach whereby neologisms are the lexemes formed for nominating new concepts to existing words. Finally, borrowing represents the act of obtaining a word or phrase from another language. The latter is a stylistic theory relevant to the words which used to be scientific terms but have been adopted by non-specialists. From each of the three categories, the ten neologisms with the highest frequency of occurrence are selected and discussed in detail. Figure (1) illustrates the three components introduced by Krishnamurthy (2010), in light of which this research will classify the newly accumulated COVID-19 vocabulary.

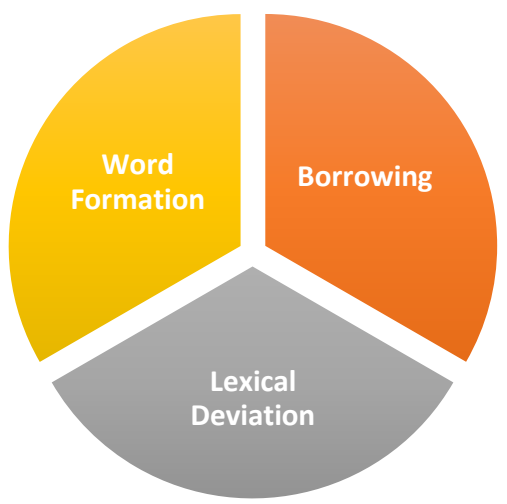

Figure 1. The components of Krishnamurthy's theoretical model of Neologism (2010).

\section{Result Analysis}

After collecting the COVID-19 related hashtags with the highest frequency, they are classified manually into three categories: a) borrowing and jargon language, b) word formation, and c) lexical deviation, as shown in Tables (1-3). The latter two classes mainly involve slang expressions and wordplay (puns, clichés) for humorous effect.

\subsection{Borrowing}

The spread of the COVID-19 virus globally was accompanied by the spread of related vocabulary. An increasing amount of medical terms have found their way into the everyday discourse of common people. Thorne (2020) defines this as the stage of "medicalisation" of everyday language, through which non-specialists become familiar with medical vocabulary related to the virus itself. An example is the term coronavirus and COVID19, which became part of the standard vocabulary used by people on a daily basis. Table (1) presents the top ten covid-related hashtags whose usage frequency remarkably peaked during the first six months of the pandemic, along with their definition and an example of usage.

As for the present case study, the act of borrowing did not take place from one language to another, but rather from jargon into common language. Jargon can be defined as the linguistic variation that involves technical vocabulary and expressions specific to a particular field of study or expertise. It was noticed that common people became gradually more aware of the meaning of these technical terms and started to use them accordingly because their daily life discourse during the pandemic required them to be able to differentiate between medical vocabulary and use it correctly. However, this is not considered to be a totally unfamiliar phenomenon in language development, as there were other similar cases observed during the outbreak of SARS in 2002 and the Swine-Flu in 2009.

\begin{tabular}{|l|l|l|l|}
\hline & Trending Hashtag & Frequency & Usage and example \\
\hline 1 & \#ClinicalTrials & 114,647 & $\begin{array}{l}\text { Clinical trials are research investigations in which people } \\
\text { volunteer to test new treatments, interventions or tests as a } \\
\text { means to prevent, detect, treat, or manage various diseases or } \\
\text { medical conditions. }\end{array}$ \\
& & $\begin{array}{l}\text { "First COVID-19 vaccine to undergo \#clinicaltrial in China } \\
\text { found to be safe \& able to generate an immune response against } \\
\text { coronavirus in humans, based on the results of a preliminary }\end{array}$ \\
\end{tabular}




\begin{tabular}{|c|c|c|c|}
\hline & & & trial." \\
\hline \multirow[t]{2}{*}{2} & \multirow[t]{2}{*}{ \#ContactTracing } & \multirow[t]{2}{*}{26,159} & $\begin{array}{l}\text { In public health, contact tracing is the process of identification } \\
\text { of persons who may have come into contact with an infected } \\
\text { person and subsequent collection of further information about } \\
\text { these contacts. }\end{array}$ \\
\hline & & & $\begin{array}{l}\text { "NHS \#contacttracing system not expected to be fully operating } \\
\text { until September. Really, you gotta laugh. What a bunch of } \\
\text { clowns." }\end{array}$ \\
\hline \multirow[t]{2}{*}{3} & \multirow[t]{2}{*}{ \#Contagious } & \multirow[t]{2}{*}{34,816} & $\begin{array}{l}\text { A contagious disease is one that spreads from one person or } \\
\text { organism to another, typically by direct contact. }\end{array}$ \\
\hline & & & $\begin{array}{l}\text { "This is a highly \#contagious disease! Contracting it may not } \\
\text { kill you, but you could infect and kill other more vulnerable } \\
\text { people. Selfish!! \#StayHomeSaveLives" }\end{array}$ \\
\hline \multirow[t]{2}{*}{4} & \multirow[t]{2}{*}{ \#Epidemic } & \multirow[t]{2}{*}{144,208} & An epidemic is a situation where a disease spreads rapidly \\
\hline & & & $\begin{array}{l}\text { "Lesson- don't gamble with people's lives. Go with trusted core } \\
\text { public health principles of \#epidemic control. Move early \& } \\
\text { lockdown not needed or is short." }\end{array}$ \\
\hline \multirow[t]{2}{*}{5} & \multirow[t]{2}{*}{ \#herdimmunity } & \multirow[t]{2}{*}{92,003} & $\begin{array}{l}\text { The ability to resist the spread of a contagious disease because } \\
\text { a population has a sufficiently high number of people immune } \\
\text { to the disease. }\end{array}$ \\
\hline & & & $\begin{array}{l}\text { "Early results from Moderna's vaccine trial suggest the vaccine } \\
\text { has the potential to give people \#herdimmunity against covid- } \\
\text { 19. But we can't draw conclusions from a Phase I trial, with data } \\
\text { from only eight participants so far." }\end{array}$ \\
\hline \multirow[t]{2}{*}{6} & \multirow[t]{2}{*}{ \#Pandemic } & \multirow[t]{2}{*}{$1,966,513$} & $\begin{array}{l}\text { A pandemic is an epidemic that has become a worldwide } \\
\text { phenomenon. }\end{array}$ \\
\hline & & & $\begin{array}{l}\text { "still trying to make sense of the fact that we don't have enough } \\
\text { face shields for hospitals dealing with a \#pandemic but we do } \\
\text { have enough for police...?? make it make sense" }\end{array}$ \\
\hline \multirow[t]{2}{*}{7} & \multirow[t]{2}{*}{$\begin{array}{l}\text { \#Quarantine, } \\
\text { \#quarantined }\end{array}$} & \multirow[t]{2}{*}{785,961} & $\begin{array}{l}\text { A quarantine is a restriction on the movement of people and } \\
\text { goods which is intended to prevent the spread of disease or } \\
\text { pests. }\end{array}$ \\
\hline & & & $\begin{array}{l}\text { "Mom says I can't come out and play because I'm still in } \\
\text { \#quarantine. \#BurrowingOwls" }\end{array}$ \\
\hline \multirow[t]{2}{*}{8} & \multirow[t]{2}{*}{$\begin{array}{l}\text { \#Selflsolation, } \\
\text { \#selflsolated, } \\
\text { \#selfIsolate }\end{array}$} & \multirow[t]{2}{*}{122,563} & $\begin{array}{l}\text { Self-isolation is when one stays at home because they have or } \\
\text { might have the coronavirus, as this helps stop the virus } \\
\text { spreading to other people. }\end{array}$ \\
\hline & & & $\begin{array}{l}\text { "Looking at the news and wondering if putting ourselves into } \\
\text { \#selfisolation for the next twenty years isn't such a bad idea." }\end{array}$ \\
\hline \multirow[t]{2}{*}{9} & \multirow[t]{2}{*}{ \#Socialdistancing } & \multirow[t]{2}{*}{287,422} & $\begin{array}{l}\text { In public health, social distancing, also called "physical } \\
\text { distancing," means keeping space between yourself and other } \\
\text { people outside of your home. }\end{array}$ \\
\hline & & & $\begin{array}{l}\text { "Thousands of Americans, like my mom, were unable to attend } \\
\text { the funerals of friends who died from COVID-19 out of respect for } \\
\text { \#socialdistancing guidelines." }\end{array}$ \\
\hline \multirow[t]{2}{*}{10} & \multirow[t]{2}{*}{ \#Vaccine } & \multirow[t]{2}{*}{427,554} & $\begin{array}{l}\text { A vaccine is a biological preparation that provides active } \\
\text { acquired immunity to a particular infectious disease. }\end{array}$ \\
\hline & & & $\begin{array}{l}\text { "There is no medicine, no \#vaccine for the pandemic but } \\
\text { CARDIO and RESPIRATORY physical therapy techniques hv gd } \\
\text { results in even critical patients where medicine and ventilators } \\
\text { can't work." }\end{array}$ \\
\hline
\end{tabular}

Discussing the new vocabulary learnt during the pandemic, Kairu states that such expressions are not really new words, but rather words that have undergone semantic shift or have gained prominence post COVID-19. Rets (2014) adds that semantic shift is not a change in meaning per se, but can add meaning to the semantic system or indicate the loss of meaning from the semantic system while the form is maintained, often because an appropriate condition is created that allows some lexical items 
to change their register and enter the public conversation. Whenever the cultural scripts shift in a society, the vocabulary or lexicon of a language will also shift simultaneously. In addition, the meanings of words themselves may change to reflect and/or promote cultural change. COVID-19 is certainly an agent of culture change and some of these changes are reflected in the way that certain words have shifted their meaning to suit the pandemic situation.

Given the ten hashtags that were found to have the highest frequency of use, these borrowed expressions are not only obtained from the medical jargon, as they might also originate in sociology or psychology. For example, \#contacttracing involves tracing people who have been in close liaison with persons infected with a virus and are at a higher risk of becoming infected themselves and are likely to infect others in the process. Keeping a close watch on such contacts after exposure will help the contacts get care and treatment and eventually prevent further transmission of the virus. When systematically applied, it can break the pattern of transmission of infectious diseases, making it an essential public health tool for controlling infectious disease outbreaks.

The terms \#epidemic and \#pandemic have also acquired prominence in the post-COVID-19 vocabulary. These terms fall under medical jargon. However, in post corona, they have become part of everyday vocabulary understood even by common people. The two terms gained prominence on March 11, 2020, when the WHO declared the new coronavirus (COVID-19) a pandemic. From this pronouncement, the difference between the two terms started to be clear for most non-specialists. An epidemic is a disease that affects many people at the same time by spreading from person to person in a locality; meanwhile, the pandemic, on the other hand, is a global outbreak of a disease emanating from a new virus. Geographically, a pandemic affects a whole country, continent or the entire world. These two jargon terms have been adopted during the COVID19 outbreak to suit the purpose of the users.

Another two terms that are now part of everyday vocabulary are \#quarantine and \#isolation. The term quarantine refers to a strict isolation regime forced on people to stop the spread of disease. The practice of a quarantine specifically involves segregating people or groups of people who may have come into contact with a communicable disease but are asymptomatic, from others who have not been exposed so as to arrest the possibility of the spread of the communicable disease. In contrast, isolation is a noun which specifically refers the act of completely separating a person suffering from contagious or infectious disease from others. People may be quarantined when they are not currently sick, but have in one way or another have come into contact with a communicable or infectious disease. On the other hand, they may be placed in isolation if they currently have a communicable disease and can potentially infect others. This act thus separates them from people who are healthy, helping to stop the spread of the disease. The term quarantine and isolation are examples of medical jargon that has been used over the years. However, due to the pandemic ravaging the world today as already existing words, they have gained more currency in their use due to the existing social situation.

\#Herdimmunity is one of the terms currently in use in the COVID-19 vocabulary and can mean group immunity or the ability to resist the spread of contagious disease because a population has a sufficiently high number of people immune to the disease. This is a term in epidemiology that describes how a population has enough immunity to an infectious disease, to the extent to which the infection is unable to spread within the population. Herd immunity can be developed naturally or through vaccinations. According to van Schaik, "Herd immunity describes a situation where individuals who are at risk are protected from infectious diseases because they are surrounded by individuals who are immune, thus minimizing the spread of the virus. Some countries have been toying with the idea of taking this approach in the fight against COVID-19. However, many nations have resorted to the WHO protocols of combating the disease. As a concept in epidemiology, it falls under medical jargon; however, under the COVID-vocabulary it is now used as an ordinary word.

4.2 Word Formation

\begin{tabular}{|l|l|l|l|}
\hline & Trending Term & Frequency & Usage and example \\
\hline 1 & \#Coronacation & 7,523 & $\begin{array}{l}\text { Corona + vacation } \\
\text { A coronacation is a cessation of study or work due to the } \\
\text { social distancing measures of the pandemic, viewed as a } \\
\text { holiday. }\end{array}$ \\
\hline 2 & \#Covidient & $\begin{array}{l}\text { Day } 77 \text { of social distancing: unofficial last day of school for the } \\
\text { boys. We have enjoyed school time together. It was far more } \\
\text { pleasant than we expected in March when \#coronacation } \\
\text { began. " }\end{array}$ \\
\hline A covidient is a person who follows the public health
\end{tabular}




\begin{tabular}{|c|c|c|c|}
\hline & & & guidelines to limit the spreads of COVID-19. \\
\hline & & & $\begin{array}{l}\text { "Be a \#Covidient, follow the rules, stay in \& stay safe! Sending } \\
\text { love to all Covidients out in there!" }\end{array}$ \\
\hline 3 & \#Covidiot & 85,724 & $\begin{array}{l}\text { COVID + idiot } \\
\text { A covidiot is a person who behaves irresponsibly in conditions } \\
\text { of containment. }\end{array}$ \\
\hline & & & $\begin{array}{l}\text { "BREAKING Police break up huge London street party as of } 100 \mathrm{~s} \\
\text { of \#covidiots ignore lockdown \#Brent" }\end{array}$ \\
\hline 4 & \#Covidivorce & 62,010 & $\begin{array}{l}\text { COVID + divorce } \\
\text { Covidivorce is a way of explaining that a relationship has } \\
\text { strained due to sustained and close quarters during the } \\
\text { lockdown. }\end{array}$ \\
\hline & & & $\begin{array}{l}\text { "How many couple now spending seven days a week together } \\
\text { will discover they're not really compatible, and end in } \\
\text { \#CoviDivorce?" }\end{array}$ \\
\hline 5 & \#Morona & 10,026 & $\begin{array}{l}\text { Moron + corona } \\
\text { The state of a person behaving stupidly because of or during } \\
\text { the coronavirus outbreak }\end{array}$ \\
\hline & & & $\begin{array}{l}\text { "I am searching for suitable land to build a detention center for } \\
\text { the RSS guys as I feel \#Morona is more dangerous than } \\
\text { Corona" }\end{array}$ \\
\hline 6 & \#Pandumbic & 4,881 & $\begin{array}{l}\text { Pandemic }+ \text { dumb } \\
\text { A covedient is a person who follows the public health } \\
\text { guidelines to limit the spreads of COVID-19. }\end{array}$ \\
\hline & & & $\begin{array}{l}\text { "Couldn't possibly have predicted that! If only they had real } \\
\text { facts \& 7data to help make an educated decision. } \\
\text { \#Pandumbic" }\end{array}$ \\
\hline 7 & $\begin{array}{l}\text { \#Quaranteens, } \\
\text { \#coronials, } \\
\text { \#coronababies }\end{array}$ & 12,717 & $\begin{array}{l}\qquad \begin{array}{l}\text { Quarantine + teenagers } \\
\text { Corona + millennials }\end{array} \\
\text { Coronials or Coronababies are the babies conceived during } \\
\text { the corona outbreak, growing up to become Quaranteens }\end{array}$ \\
\hline & & & $\begin{array}{l}\text { "So will all the babies born } 9 \text { months after these quarantines be } \\
\text { called \#coronababies? \#coronapocolypse" } \\
\text { "According to three tests today, my wife's pregnant........they } \\
\text { WARNED us this would happen, America! \#quaranteens" }\end{array}$ \\
\hline 8 & \#Quaranteams & 3,615 & $\begin{array}{l}\text { Quarantine + teams } \\
\text { Quaranteams are online gaming teams created during } \\
\text { lockdown. }\end{array}$ \\
\hline & & & $\begin{array}{l}\text { "if we're all gonna form Quaranteams, we need \#Quaranteam } \\
\text { names" }\end{array}$ \\
\hline 9 & \#Trumpdemic & 2,251 & $\begin{array}{l}\text { Trump + pandemic } \\
\text { Criticizing Trumps late decision-making concerning the } \\
\text { COVID-19 outbreak, many users blame Trump for the spread } \\
\text { of pandemic in the US. }\end{array}$ \\
\hline & & & $\begin{array}{l}\text { "When was the last time you talked about the \#trumpdemic? } \\
115,000 \text { dead Americans and now you just ignore it? That's not } \\
\text { going to get you re-elected. I promise you that." }\end{array}$ \\
\hline 10 & \#Covexit & 6,368 & $\begin{array}{l}\text { COVID + exit } \\
\text { A covexit is a strategy to escape the lockdown. }\end{array}$ \\
\hline & & & "I can't wait to \#COVEXIT the Rona lockdown!!" \\
\hline
\end{tabular}

Words in a language may be created through blending, whereby two words are brought together to create a new word that combines their meanings. However, in blending, unlike compounding, only parts of the words are used usually after undergoing a clipping process. In the creation of these kinds of neologisms, the beginning of one word can be combined with the end of another word. Certain words in the COVID-19 vocabulary have been created using this strategy. For instance, the term COVID-19 
itself is a blending derived from Corona Virus Disease, whereas the number 19 identifies the year in which the outbreak began. The majority of slang words were created similarly to evoke a humorous effect, which in turn increased their frequency of use.

As shown in Table (2), language users have been creative in forming new words to describe new situations for which no sufficient expression existed yet. The main change to the daily routine of people worldwide is the lockdown and curfews, which forced people to stay at home for at least a number of weeks. A \#coronacation blends corona and vacation and refers to the obligatory form of "vacation" for workers, as they were prevented from going to their workplaces and mostly had to manage their responsibilities remotely from their home. The restrictions on leaving one's place during the quarantine also encouraged the act of \#coronacocooning, which means to wrap oneself in the comforts of one's place and to hide from the risk of getting infected by the virus. The Coronacation, in turn, has a blurring effect on the perception of time, making all days feel the same such that every day turns into a Blursday rather than something more specific.

Another example of blending is \#coronapocalypse, obtained through blending "corona" and "apocalypse"-the word play centers around "apocalypse" which is added to the word corona. Given the biblical reference of the apocalypse that indicates the end of time, the term is used to convey humorous effects, so as a form of coping with the difficulties and challenges faced during the COVID-19 pandemic.

A remarkable aspect when taking a look at the most frequently used neologisms of this kind is the fact that more than half of the words are used to categorize people based on different factors. To start with, the attitude of people towards the virus divides them into \#covidients and \#covidiots. The term covidiot is a blend of "COVID-19" and "idiot", it is used as a slang insult against anyone who ignores the WHO health and safety guidelines concerning the new virus. A covidiot is one who exhibits the following characteristics: not washing their hands regularly, one who mingles in large groups of people, someone who does not observe social distancing that is the six-feet distance between people. On the other hand, a covidient is a person who is responsible and follows all the requirements and regulations of the lockdown and social distancing. Another term that is used to insult people who are not following the health directives is \#morona virus, a combination of moron and corona. The wordplay is centred around the word moron, to which the term virus is added. The two terms (covidiot and moronavirus) can also be viewed as a form of quarantine shaming.

New coinages include expressions for conceptualizing the new types of relations. \#Quaranteams are the people with whom the lockdown is spent, often represented by the immediate family members, roommates, or friends. On the other hand, some marriages or relationships failed to withstand the lockdown test, as they could not bear to spend with each other all the time during the quarantine, which resulted in a new type of divorce, namely the \#covidivorce. Finally, certain words and expressions have been created to refer to different generations. The most remarkable ones are the \#coronababies, \#quaranteens, and \#coronials, which refers to the generation born after December 2020 and who will become teenagers during 2030-2040.

\subsection{Lexical Deviation}

As a neologism, coinage is a process of word formation in which a new word or expression is created either intentionally or fortuitously. A coinage can also be viewed as the invention of totally new terms. Some examples from everyday use of language include aspirin, nylon, vaseline, Kleenex, and google. Even though coinages are a rare method of creating new words, some COVID-19 vocabulary is created using this strategy. Table (3) presents the new expressions resulting from lexical deviation. This form of neologisms was mainly observed in common discourse rather than in tweets from official healthcare organizations and institutes or medical and scientific conferences.

\begin{tabular}{|l|l|l|l|}
\hline & Trending Term & Frequency & Usage and example \\
\hline 1. & \#Cornteen & 8,541 & $\begin{array}{l}\text { As quarantine sounds rather serious, millennials have created } \\
\text { the term corn-teen which seems less threatening, being } \\
\text { originated as a misspelling. }\end{array}$ \\
\hline 2. & \#Coronabreak & $\begin{array}{l}\text { "My household was exposed to someone who tested positive for } \\
\text { covid-19 \& we've been \#cornteen \& y'all still want me to go } \\
\text { out with y'all talking bout "but you're not sick" \#jeeez \#covidiot" }\end{array}$ \\
\hline 3. & \#Coronacuts & $\begin{array}{l}\text { Similar to a coronacation, a corona break is a cessation of } \\
\text { study or work due to the social distancing measures of the } \\
\text { pandemic, viewed as a holiday. }\end{array}$ \\
\hline & & $\begin{array}{l}\text { "After this \#coronabreak, I'm taking a whole month off kitchen } \\
\text { duties." }\end{array}$ \\
\hline
\end{tabular}




\begin{tabular}{|c|c|c|c|}
\hline & & & $\begin{array}{l}\text { one's own hair due to the closure of hair salons, or the act of } \\
\text { taking on the role of a hair dresser for family members during } \\
\text { quarantine. }\end{array}$ \\
\hline & & & $\begin{array}{l}\text { "New clippers - new haircuts. We both still look a bit rough } \\
\text { around the edges. \#Coronacuts" }\end{array}$ \\
\hline \multirow[t]{2}{*}{4.} & \multirow[t]{2}{*}{ \#Covid19lbs } & \multirow[t]{2}{*}{25,764} & $\begin{array}{l}\text { This is a humorous expression used to describe the extra body } \\
\text { weight gained during quarantine. }\end{array}$ \\
\hline & & & $\begin{array}{l}\text { "Has anyone else gained the \#Covid19lbs staying at home } \\
\text { doing nothing all day every day for the last } 2 \text { months!?" }\end{array}$ \\
\hline \multirow[t]{2}{*}{5.} & \multirow[t]{2}{*}{ \#Doomscrolling } & \multirow[t]{2}{*}{42,181} & $\begin{array}{l}\text { It is the inability to peel one's eyes away from phones and } \\
\text { computers, constantly refreshing our news feeds for the latest } \\
\text { posts about the pandemic. }\end{array}$ \\
\hline & & & $\begin{array}{l}\text { "So, when you finally force yourself to accomplish something } \\
\text { after hours of \#doomscrolling, remember that you're actually } \\
\text { doing a revolutionary act." }\end{array}$ \\
\hline \multirow[t]{2}{*}{6.} & \multirow[t]{2}{*}{ \#ElbowBump } & \multirow[t]{2}{*}{19,577} & $\begin{array}{l}\text { The elbow bump is an informal greeting where two people } \\
\text { touch elbows. Interest in this greeting was renewed during the } \\
\text { COVID-19 outbreak. }\end{array}$ \\
\hline & & & $\begin{array}{l}\text { "Something that I'm finding very strange at the moment is not } \\
\text { shaking hands with people. I don't like the new \#elbowbump" } \\
\text { at all. I like to shake peoples' hands and it seems strange not to } \\
\text { do it." }\end{array}$ \\
\hline \multirow[t]{2}{*}{7.} & \multirow[t]{2}{*}{ \#KungFlu } & \multirow[t]{2}{*}{58,321} & $\begin{array}{l}\text { This term was initially used by an unnamed White House } \\
\text { official to refer to the deadly coronavirus as the "Kung-Flu". } \\
\text { Being intended as a mere joke, it was heavily criticized for } \\
\text { several reasons. }\end{array}$ \\
\hline & & & $\begin{array}{l}\text { "Trump tried to stoke hate against Asians saying Wuhan Virus, } \\
\text { Chinese Virus, and \#KungFlu." }\end{array}$ \\
\hline \multirow[t]{2}{*}{8.} & \multirow[t]{2}{*}{ \#MileyCyrus } & \multirow[t]{2}{*}{2,859} & $\begin{array}{l}\text { The name of the pop-artist has been used as a Cockney } \\
\text { rhyming slang expression to replace the coronavirus. }\end{array}$ \\
\hline & & & $\begin{array}{l}\text { "After much debate with qualified academics (i.e. my mates in } \\
\text { the pub) it has been decided that the correct Cockney rhyming } \\
\text { slang for Corona Virus is \#MileyCyrus." }\end{array}$ \\
\hline \multirow[t]{2}{*}{9.} & \multirow[t]{2}{*}{ \#MissRona } & \multirow[t]{2}{*}{81,682} & $\begin{array}{l}\text { Miss Rona is a personification of the virus as a villain who does } \\
\text { not play around. }\end{array}$ \\
\hline & & & $\begin{array}{l}\text { "A lot of things wouldn't have happened this year if \#missrona } \\
\text { wasn't around" }\end{array}$ \\
\hline \multirow[t]{2}{*}{10.} & \multirow[t]{2}{*}{ \#QuarantineandChill } & \multirow[t]{2}{*}{102,358} & $\begin{array}{l}\text { As a variation of the expression Netflix and Chill, families who } \\
\text { are quarantined together are doing a lot of leisure activities } \\
\text { together. This phrase is used to make it sound more like a } \\
\text { choice and less like a government mandate. }\end{array}$ \\
\hline & & & $\begin{array}{l}\text { "On today's episode of \#QuarantineandChill...I cleaned all of } \\
\text { my shoes Athletic shoes" }\end{array}$ \\
\hline
\end{tabular}

Wordplay has been a crucial factor in the formation of the new vocabulary. Being the hot topic of most news discussions and private conversations, coronavirus-a word too long for the phonetic pattern of the English sentence-was shortened to (the) Rona in informal conversations. Rona is made of double clipping and is a playful or sarcastic way of referring to COVID-19, especially in respect to the amusing challenges brought about by social distancing during the pandemic. Rona, therefore, is a term that brings humour and some form of relief. The term Rona is an example of a coinage that is compelled by the linguistic economy, just like the use of abbreviations. Another term to denote the disease, Miley Cyrus, is based on phonetic similarity to the singer Miley Cyrus. The outbreak seems to have become a remarkable milestone, so it is now used as a temporal reference point: the abbreviation BC does not only stand for before Christ but it has also come to mean before coronavirus.

Among the different ways in which the new virus has changed our daily lives, it has remarkably affected people's appearances. One example is the \#coronacut, which are haircuts made at home due to the curfew that prevents people from going to the barber or the hair salon. Another impact is the gaining of weight during the lockdown, mostly because the gyms are shut down 
and people are forced to stay at home. This is referred to as the \#Covid19lbs, being a humorous way to indicate the gain of about twenty pounds within a short period of time.

Considering daily life behaviour, many people during the lockdown became addicted to social media's constant use for many hours. This involved checking online news platforms and social media posts to remain up to date about the latest developments of the virus, and at the same time follow the activities of friends and family members during the pandemic. This is better known as \#doomscrolling, which describes the inability of people to leave the smartphones and computers aside, as they constantly refresh the news feeds for the latest posts about COVID19. Given the social distancing health regulations, people are not allowed to shake hands anymore to prevent the possible spread of the disease from one person to another. As an alternative solution, the \#elbowbump was re-introduced, which is an informal way of greeting whereby people touch elbows.

\section{Discussion}

According to Nordquist (2019), language change is an occurrence by which alterations are made in the attributes and the use of a language over time. Language changes can be manifested in its sound patterns, lexis, semantics, and syntax, and they may be either systematic or sporadic. During a time of social crises like COVID-19 pandemic, languages witness an explosion of new words and phrases like the ones discussed above. The neologisms addressed above are useful since they function to help people communicate their fears about the biggest health crisis ever seen in generations. It collates people around a set of collective cultural reference points - it, therefore, acts as a kind of lexical "social glue". The instant access to social media, which is now part of our lives - has made it possible for people to share content with friends and family through our online connections.

The hashtag in particular, is a highly efficient way of connecting people online, as they can be created by anyone within particular restrictions. All similar hashtags that are used in different posts and by different users are connected through its hyperlink, which in turn enables social media users to view all the public posts across the social media platform that include the same hashtag simply by clicking on it. Given the ease of use and adoption of hashtags online, it is very easy for users to create new words and vocabulary, and for others to adopt it as part of their own posts which eventually increase the spread of its usage.

The use of neologisms can be accounted for within Halliday's theory (2013) that stipulates that languages change to accommodate the needs of their users. According to Halliday, language operates differently in different social situations, and it is bound to vary to suit the purpose of the users or a particular social situation. In this case, language uses different techniques such as borrowing, word formation or lexical deviation to create words that are used during the COVID-19 pandemic. Therefore, each neologism unfolds in some context of use, which also gives it its function to keep people informed about the COVID19. Another function is to bring humour that can help people cope with the stress occasioned by COVID-19, as wordplay often serves to bring people closer together. Slang insults such as covidiot and moronavirus are used to shame those who do not follow health protocols in the fight against COVID-19.

\section{Conclusion}

Given the fact that no social phenomenon can avoid being represented in language, the linguistic 'response' of society when exposed to the COVID19 pandemic is the huge number of neologisms observed in online discourse on social media platforms. Drawing on the assumption that language units verbalise cultural phenomena, it can be concluded that the modern Englishspeaking society undergoes a number of cultural changes, such as medicalising public discourse to engage them in the struggle against COVID-19, introducing new categories for social groups according to attitude to the pandemic or socially responsible behaviour, and developing new/modifying old lifestyle practices like appearance, interpersonal relationships, and patterns of online and off-line communication.

The three forms of neologisms proposed by Krishnamurthy were all observed in the examined discourse, represented by borrowing medical, sociological, and psychological terms into the language of common people and creating new vocabulary through word formation and lexical deviation. The analysis of the new expressions and terms gave an insight into novel cultural practices involved with the public discourse centred around COVID19. This new vocabulary helps people articulate their worries about the biggest health crisis witnessed in decades. It brings people together around a set of collective cultural reference points - a kind of lexical "social glue". Therefore, the pandemic in the English language lies primarily within the scope of lexicology: conceptualisation of new phenomena requires either new words/expressions or reconsideration of old words/expressions endowed with new meanings.

The other consequence of the pandemic belongs to the sphere of discourse, communication, and culture. The conclusion is drawn that one of the biggest factors in the spread of coronavirus terminology is the fact that we are more digitally connected than ever before. Instant access to social media is now an integral part of our lives - and we share content with friends and 
family through a variety of social media outlets. The hyperlinked hashtag, in particular, has a crucial role in spreading the new words and expressions on Twitter, as its ease of use encouraged users to create, alter, and adopt neologisms as part of their online discourse. The scale of our online connections implies more opportunities for online users to create and share neologisms beyond their immediate local communities.

Funding: This research received no external funding.

Acknowledgments: The authors would like to acknowledge the Department of English at the College of Education for Human Sciences, University of Babylon, for providing the inspiration and support to carry out this study.

Conflicts of Interest: The authors declare no conflict of interest.

\section{References}

[1] Krishnamurthy, S. (2010). The chutnification of English: An examination of the lexis of Salman Rushie's Midnight's Children. Journal of social and cultural studies, 13(1) 11-28.

[2] Goldberg, M. H., Gustafson, A., Maibach, E. W., van der Linden, S., Ballew, M. T.,Leiserowitz, A. (2020, May 4). Social Norms and COVID-19 Preventive Behaviors. Working paper. https://doi.org/10.31234/osf.io/9whp4

[3] Van Bavel, J. J., Baicker, K., Boggio, P. S., Capraro, V., Cichocka, A. ..., Willer, R. (2020). Using social and behavioural science nto support COVID-19 pandemic response. Nature Human Behaviour, 4, 460-471. https://doi.org/10.1038/s41562-020-0884-z

[4] Asif, M., Deng, Z., Hussain. (2019). The Case Study of Pragmatic Failure in Second Language of Pakistani Students. International Journal of English Linguistics, 9(4).

[5] Crystal, D. (2001). Language and Internet. Cambridge, UK: Cambridge University Press.

[6] Khan, M. (2013). Neologisms in Urdu A Linguistic Investigation of Urdu Media. Language in India, 13(6).

[7] Janssen, M. (2005) "Between Inflection and Derivation: Paradigmatic Lexical Functions in Morphological Databases". Em: East West Encounter: second international conference on Meaning \& Text Theory. Moscovo: Rússia.

[8] Rets, I. Studying the new vocabulary of the Dutch language in the context of globalization. Philological sciences. Theoretical and practical questions, 6, 149-152, 2014.

[9] Halliday, M. A. K. Introduction to Functional Grammar. Hodder Arnold. 2013

[10] Janssen, M. (2005). Between Inflection and Derivation Paradigmatic Lexical Functions in Morphological Databases.

[11] Peprnik \& Jaroslav (2006). English Lexicology. Olomouc: Univerzita Palackeho v Olomouci.

[12] Qaisar, K. (2015). The Diary of a Social Butterfly. European Academic Research. Vol. II.

[13] Rey, A. (1995). Essays on Terminology. Amsterdam. John Benjamins Publishing Company.

[14] Thorne, T. (2020, June 1). Spotlight on COVID: Pandemic language and the role of linguistics. King's College London. News Centre. Retrieved from https://www.kcl.ac.uk/news/spotlight-on-covid-pandemic-language-and-the-role-of-linguists-1

[15] Sahu, K. K., Mishra, A. K., \& Lal, A. (2020). Comprehensive update on current outbreak of novel coronavirus infection (2019-nCoV). Ann Transl Med.

[16] Štekauer, P. (1998). An onomasiological theory of English word-formation. John Benjamins.

[17] Richard Nordquist (2019), Language Change, Glossary of Grammatical and Rhetorical Terms. ThoughtCo. Online available: https://www.thoughtco.com

[18] Usevičs, S. (2013). Neologisms in British Newspapers. Retrieved from: https://pdfs.semanticscholar.org/1dd8/c7e932e8670ccc9ae24cfa90dc809f434c 07.pdf

[19] Coronavirus Glossary. https://relief.unboundmedicine.com/relief/view/Coronavirus-Guidelines/2355004/all/Coronavirus Glossary of Terms\#8 Accessed 20 April 2020.

[20] Coronavirus Glossary. https://time.com/5798684/coronavirus-glossary-definitions/ Accessed 28 April 2020.

[21] Language of Covid-19. https://public.oed.com/blog/the-language-of-covid-19/ Accessed 22 April 2020.

[22] Oxford Corpus. https://public.oed.com/blog/corpus-analysis-of-the-language-ofcovid- 19/ Accessed 27 April 2020.

[23] Oxford Dictionary. https://www.theguardian.com/books/2020/apr/15/oxforddictionary

[24] Bilefsky, D., \& Yeginsu, C. (2020, March 27). Of 'Covidivorces' and 'Coronababies': Life During a Lockdown. New York Times. Retrieved from https://www.nytimes.com/2020/03/27/world/coronavirus-lockdown-relationships.html

[25] Kim, H. T., Woods, P., Azman, H., Abdullah, I. H., Hashim, R. S., Rahim, ... Kosem, I. COVID-19 Insights and Linguistic Methods. 3L: The Southeast Asian Journal of English Language Studies, 26(2), 1-23. https://doi.org/10.17576/3L-2020-2602-01

[26] Koltsova, E. A. (2017). Neologisms in the English Language in the 21st century. RUDN Journal of Language Studies, Semiotics and Semantics, 8(3), 604-613. https://doi.org/10.22363/2313-2299-2017-8-3-604-613

[27] Song, S. (2020, May 2). New social norms emerge in the age of COVID-19. The Korea Herald. Retrieved from http://www.koreaherald.com/view.php?ud=20200429000273

Bauer, L. (1994). Watching English Change. London: Longman. 